in the Cumberland Infirmary, Carlisle, from 1947 until 1948, he joined H.M. Colonial Medical Service in 1948. $\mathrm{He}$ then held various appointments in Malaya, and while at the Institute of Medical Research at Kuala Lumpur did research on virus diseases. In $1957 \mathrm{Dr}$. Smith was appointed senior lecturer in bacteriology at the London School of Hygiene and Tropical Medicine. In 1960 he became a menuber of the World Health Organization's study group on arthropod-borne viruses. Since 1961 Dr. Smith has been reader in virology in the University of London at the London School of Hygiene and Tropical Medicine. $\mathrm{He}$ is also head of the Arthropod-borne Virus Research Unit financed by the Department of Technical Co-operation.

\section{Human Environment in the Institute of Archæology: Prof. G. W. Dimbleby}

DR. G. W. DrmbleBy, who has recently been appointed to the chair of human environment in the Institute of Archæology, London, took an honours degree in botany at Oxford in 1939. He later worked on soil problemsparticularly on oxidation-reduction potentials as measures of soil activity. During the Second World War, he was in the Royal Air Force and applied his powers of observation and his ecological training to the interpretation of air photographs and was largely instrumental in developing methods for the detection of decoy sites in enemy-occupied territory designed to lead Allied bombers astray. After the War, Dr. Dimbleby was appointed as ecologist in the Forestry Department of the University of Oxford. His early work on heathlands was concerned with the natural succession back to deciduous woodland if the heaths were protected from fire. He found that this was accompanied by progressive regeneration of the soil which implied that the poor state of the soil under hesthland did not reflect its full potential. To find out what this might have been, Dr. Dimbleby set out to investigate soils buried beneath earthworks of different ages, using pollen analysis and comparative soil typology as his main tools. It became apparent that the process of deterioration had its origin in the initial forest clearance by Bronze-Age (or even earlier) man, and that it was not determined purely by climate or parent material. The original forest was a mixed deciduous one on a brown forest soil, but traces of podzolization appeared during the farming phase which followed clearance and the process of degradation has continued ever since. On the face of it, it may seem a far cry from forestry to archæology, but Dr. Dimbleby's botanical and pedological investigations have revealed such a close connexion between the activities of early man and the state of the land to-day (and therefore its use) that his work has been fundamental to both disciplines.

\section{Deputy Director of Mullard Research Laboratories : Dr. K. Hoselitz}

Dr. K. Hoselitz has been appointed deputy director of Mullard Research Laboratories. He will continue as head of the Laboratories' Solid State Physics Division. Dr. Hoselitz was educated at the Universities of Vienna and Bristol. He gained his Ph.D. at Bristol in 1942 and afterwards joined the Permanent Magnet Association as a research scientist. $\mathrm{He}$ was promoted director of the Association's Central Research Laboratories in 1947. In 1952 he joined Mullard Research Laboratories to establish the Solid State Physics Division. The Division has since grown to a strength of more than 100 and has made notable contributions in the fields of semiconductors, magnetic materiais and low-temperature physics. Dr. Hoselitz, whose special subjects are magnetism and the properties of metals and alloys, is the author of a textbook on those subjects and has contributed to several other books. Mullard Research Laboratories are near Redhill, Surrey, and employ about 700 people, of whom more than 200 are graduate scientists.

\section{Post Office Research Station}

IT has been announced that the Post Office Research Station at Dollis Hill is to be moved to the vicinity of Martlesham, in Suffolk. The aim is to start the move about 1968. The Research Station, which employs some 1,400 staff, has occupied its present site at Dollis Hill, London, since 1912. It has been recognized for some time that the Station would have to be moved because the present site is severely congested and there is not enough space to allow for development. The area chosen is less than $2-h$ travelling time from London, and is near the University of Essex.

\section{Agricultural Research Council Unit of Nitrogen Fixation}

The Agricultural Research Council has announced, in consultation with the authorities of Queen Mary College, University of London, that its Unit of Nitrogen Fixation will be leaving the College owing to difficulty of accommodation there. It is being transferred to the University of Sussex, where new laboratories will be erected to accommodate it. The Unit will continue to be directed by Prof. J. Chatt, who is resigning the chair of inorganic chemistry at Queen Mary College. The Unit was established to investigate the mechanism of nitrogen fixation. Dr. J. R. Postgate, formerly of the Microbiological Research Station, Porton, is in charge of the biological aspects of the research.

\section{Steroid Reference Collection}

A Steroid Reference Collection, established by the Medical Research Council, on the advice of their Clinical Endocrinology Committee and with the aid of generous gifts of steroids from the pharmaceutical industry, can supply to laboratories working on steroid metabolism, small quantities (about $2 \mathrm{mg}$ ) of reference steroids. These steroids, which are mainly hormone metabolites, are intended as standards for such procedures as paper chromatography, colour reactions, infra-red measurements and mixed melting-point determinations; larger quantities $(5-20 \mathrm{mg})$ can, on occasion, be supplied for studies of new analytical procedures. Applications for samples, with a brief statement of the purpose for which they are required, should be sent to Prof. W. Klyne, Chemistry Department, Westfield College, London, N.W.3, from whom a list of available compounds can also be obtained.

\section{Water Pollution Research}

ANYONE revolted by sewage solids on beaches will welcome the investigations described in the recent report of the Department of Scientific and Industrial Research Water Pollution Research Board (Water Pollution Research, 1963. Pp. vi $+142+4$ plates. London: H.M.S.O., 1964. 8s. 6d. net). The results indicate that maceration and screening can prevent visual offence without increasing the concentration of coliform bacteria in the sea. It should be possible to site discharges so that the concentrations of coliform bacteria (and hence pathogens) encountered by bathers signify a negligible risk of infection. Better treatment of industrial and domestic wastes is an important part of the work of the Laboratory, leading to cleaner rivers. In particular, the analysis made of the conditions favouring the oxidation of ammonia to nitrate in the activated sludge process should enable more works to attain consistent nitrification. Work on rivers continues to concentrate on the toxicity of various effluent materials and the oxygen balance. Investigations of individual toxins enable predictions to be mado of the toxicities of mixtures of toxins. These agree well with experimental observations and can be used to show the dilution needed for an effluent, or if the removal of one toxic factor would allow fish to inhabit the river. It is important for all aquatic biologists to note that a sig. nificant source of error in the standard Winkler procedures 